\title{
Current Situation and Solutions in Handling Archival Records in Digital Format
}

\author{
LINH NGUYEN, PH.D. \\ Hanoi University of Home Affaire \\ e-mail: nguyenngoclinh.edu@gmail.com, icd.huha@gmail.com \\ THUY TRAN, PH.D. \\ Hanoi University of Home Affaire \\ e-mail: tranvanthuy0712@gmail.com,icd.huha@gmail.com
}

\section{Current Situation and Solutions in Handling Archival Records in Digital Format}

\begin{abstract}
Archival records in the digital format (also called electronic archival records) are formed on the basis of data messages or documents digitized in information carriers during the operation of individuals, organizations and state offices. The Socialist Republic of Vietnam has issued some documents which act as legal base for the management of digital archival records. However, this insufficient system of legal documents along with weak material and technical/technological basis has difficulties in confronting the handling process of electronic archival records in Vietnam nowadays. In the current situation, Vietnam needs to have timely and synchronous measures so as to well process its electronic archival records.
\end{abstract}

Key words: Archive records, Electronic archival records, Electronic archival records, Information carriers

Situazione attuale e soluzioni per gestire documenti archivistici in formato digitale

\section{SINTESI}

I documenti archiviati in formato digitale (detti anche archivi elettronici) sono costituiti sulla base di messaggi di dati o documenti digitalizzati nei vettori informatici durante le attività di individui, organizzazioni ed uffici statali. La Repubblica socialista del Vietnam ha emanato alcuni atti che fungono da base giuridica per la gestione degli archivi digitali. Tuttavia, questo sistema di documenti legali, con deboli materiali e basi tecnico-tecnologiche, incontra difficoltà nell'affrontare il processo di gestione dei documenti archivistici elettronici nel Vietnam odierno. Nella situazione attuale, il Vietnam deve disporre di misure tempestive e sincrone per elaborare correttamente i propri archivi elettronici.

Parole chiave: documenti archivistici, documenti archivistici digitali, vettori informatici

Trenutna situacija in rešitve za ravnanje $\mathrm{z}$ arhivskim gradivom $\mathrm{v}$ digitalnem formatu

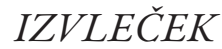

Arhivski zapisi v digitalni obliki (imenovani tudi elektronsko arhivsko gradivo) se oblikujejo na podlagi podatkovnih sporočil ali dokumentov, ki so digitalizirani med delovanjem posameznikov, organizacij in državnih ustanov. Socialistična republika Vietnam je sprejela nekaj dokumentov, ki predstavljajo pravno podlago za upravljanje z digitalnim arhivskim gradivom. Vendar pa ta nezadosten sistem pravnih dokumentov, skupaj s šibko materialno in tehnično-tehnološko osnovo, povzroča danes v Vietnamu težave pri upravljanju z elektronskim arhivskim gradivom. V trenutnih razmerah morajo imeti v Vietnamu pravočasne in sinhronske ukrepe, da bi lahko dobro strokovno obdelali svoje elektronsko arhivsko gradivo.

Ključne besede: arhivsko gradivo, elektronsko arhivsko gradivo, nosilci informacij 


\section{Introduction}

Electronic archival records are collections of correlated electronic materials and documents in respect of an issue, an event or a particular subject or subjects of same characteristics, which are formed in the work operation and supervision practiced under the functions and obligations of individuals, unitization and state offices. Creating electronic archival records is thus the act of applying information technology to unite electronic archival records yielded during the process of supervising, solving work performance of individuals, organizations and state offices into electronic format ${ }^{1}$.

The advantages of employing electronic archival records into the management are timely and ways to quickly access, share and exchange information while saving time, expense and labor, which all result in improved labor productivity and effectiveness. In addition, performing work through electronic archival records helps connect employees in an unitization, between headquarters and their subordinate units, effectively shortening physical distance among them. In particular, everyone can be a part of work performance at the same time, which is varied according to requirements of each unitization or administrative unit.

Vietnam has issued a number of documents which act as a legal base for the general management of electronic archival records such as Electronic Exchange Law (2005), Information and Technology Law (2006), Archival Law (2011), Online Information Safety Law (2015) and other decrees and instructions circulars. On 14/10/2015, Vietnam Government promulgated the Decree 36a/NQ-CP on Electronic Government (2015) on its path of applying modern information technology to the country's development and international integration. However, thelegal documents on regulations of the management of electronic archival records in general and the processing of electronic archival records in particular have been insufficient and unsystematic, posing difficulties to organizations and state offices when being put into practice. The fact has shown that the process of handling electronic archival records is a decisive element to the success of the scientific unitization of archival records in each state office and unit.

\section{Current regulations on the management of electronic archival records in general and the handling of electronic archival records in particular}

Basically, treating/handling electronic archival records can be understood as applying information and technology instruments such as hardware and software to controlling the process of forming, rotating, accessing and archiving electronic archival records. Electronic record treating consists of two phases, in one phase the electronic archival records are kept in paper processing office, in the other they are transferred to the administrative organizations' archival unit.

To ensure the legal base and provide effective instructions on a broad scale for the handling of electronic archival records in different organizations and state offices, Vietnam has promulgated specific regulation documents as follows:

- Electronic Exchange Law, No 51/2005/QH11 passed by the National Assembly of the Socialist Republic of Vietnam, session XI on 29/11/2005;

- Information and Technology Law, No 67/2006/QH11 passed by the National Assembly of the Socialist Republic of Vietnam, session XIII on 29/6/2006;

- Archival Law, No 01/2013/QH13 passed by the National Assembly of the Socialist Republic of Vietnam, session XIII on 11/11/2011;

- Online Information Safety Law, No 86/2015/QH13 passed by the National Assembly of the Socialist Republic of Vietnam, session XIII on 19/11/2015;

- Online Information Safety Law, No 104/2016/QH13 passed by the National Assembly of the Socialist Republic of Vietnam, session XIII on 06/4/2016;

- Decree No 26/2007/ND-CP promulgated on 15/02/2009 by the Government of the Socialist Republic of Vietnam, detailing regulations on digital signatures and certifying service of digital signatures;

- Decree No 64/2007/ND-CP promulgated on 10/04/2007 by the Government of the Socialist Republic of Vietnam, on applying information and technology to the operation of State organizations;

1. Decree No 1/20012/ND-CP issued on 03/1/2013 by Vietnamese Government regulating in details the operation of Archive Law's terms. 
- Decree No 71/2007/ND-CP promulgated on 03/05/2007 by the Government of the Socialist Republic of Vietnam, detailing regulations and providing guidance on realizing some termsin Information and Technology Law on information and technology industry;

- Decree No 01/2013/ND-CP promulgated on 03/01/2013 by the Government of the Socialist Republic of Vietnam, detailing regulations on executing some terms in Archival Law;

- Decree No 36a/ND-CP promulgated on 14/10/2015 by the Government of the Socialist Republic of Vietnam on electronic Government;

- Instruction No15/CT-TTg on 22/5/2012 by The Prime Minister of the Socialist Republic of Vietnam on boosting the use of electronic archival records in the State organizations' operation;

- Decree No 26/2007/ND-CP promulgated on 15/02/2007 by the Government of the Socialist Republic of Vietnam, detailing regulations on digital signatures and certifying service of digital signatures;

- Decision No 176/QD-VTLTNN on 21/10/2011 promulgated by State Records Management and Archives Department of Vietnam, regulating the procedures and instructions on carrying out the process of digitalizing archival records to set up insurance copy and in-use copy;

- Decision No 310/QD-VTLTNN on 21/12/2012 promulgated by State Records Management and Archives Department of Vietnam, stating the process of setting up the database for archival records;

- Guide No 169/HD-VTLTNN promulgated by State Records Management and Archives Department of Vietnam on 10/03/2010 on the construction of archival database;

- Guide No 822/HD-VTLTNN promulgated by State Records Management and Archives Department of Vietnam on 26/8/2015, instructing the management of incoming and outgoing documents and the filing in the online environment.

The above mentioned documents are an important legal base in electronic archival records management of any organizations and State offices, taking its part in perfecting the Electronic Government and enhancing the operation of 'offices without writing papers'. The contents of these documents are related to the management of electronic archival records, the application of information and technology to the electronic exchange, supplying information, the unitization of public services and the development of the electronic government, viz:

- First, stipulating general regulations on electronic archival records, which include definitions of Materials/documents, data message, electronic archival records, filing/setting up electronic archival records, input data, information system, information and technology, digital information, information and technology application, electronic diploma, digital signature certification, digital signature program, data, database, electronic exchange, electronic means, etc.

- Second, stipulating the conditions to form and exchange electronic archives, electronic archival records, which include regulations on electronic exchange in the operation of state organizations, in the civil domains, business, commerce and trading of individuals, companies and units which opt for doing the trading via electronic means; regulations on the enhanced use of electronic documents in the operation of State units; detailed regulations on digital signatures and digital certification, the management, supply and use of digital signature certification service; regulations on the requirements/standards of specification data, input information in respect of electronic database.

- Third, setting general regulations on the process of treating electronic archival records, which includes the process of practising professional skills in value appraisal, collection, supplementation, preservation, and assessing of electronic archival records; the digitation of archival records in information carriers during the operation of individuals, organizations and state offices.

- Fourth, forming the regulations on the operation of the electronic government, the application and development of the information and technology, measures ensuring rights and obligations of individuals, organizations and state units taking part in the information and technology development and application; regulations on supplying online information and public services on electronic websites or electronic portals; regulations on conditions ensuring the operation of the electronic portals of state units; regulations on the information technology industry, measures ensuring the development of the information and technology industry; re- 
gulations on applying standards of formatting open-materials to the uploading, exchanging and archiving of digital records in state units; regulations on requirements, standards and rules for information access.

\section{Difficulties in electronic archival records processing in Vietnam nowadays}

Although the State, relevant ministries and appropriate authorities have issued varied regulations on electronic archival records management and processing, the operation and management of electronic archival records in Vietnam has still faced with some existing difficulties, as follows:

\subsection{In terms of the system of documents regulating and instructing the process of electronic archival records processing}

Firstly, in the general regulations on electronic archival records processing, the explanations of the technical terms are still vague and lack of specification. Moreover, Vietnam has not yet systemically promulgated regulation documents which would detail the online exchange process of electronic archival records, documents on professional instructions related to material management and processing, technical requirements on material formatting, on electronic mega data, on common software used in the operation of different organizations and state units. This leads to encumbrances to the organizations and state units in their plan construction and project development concerning the internal electronic archival records management.

Secondly, after the promulgation of such laws as Electronic Exchange (2005), Information and Technology (2006) and Archival Law (2011), the National Assembly of Vietnam also passed a number of laws related to electronic archival records management, information and technology application to electronic exchange such as Online information safety Law (2015), Information access law (2016). They are all legal documents comprising general regulations and rules for a variety of subjects on a broad scale. In the meantime, Decrees and circulars constructing the realization of such laws have just been carried out in state units. For example, we do have Decree No 36a/ND-CP promulgated on $14 / 10 / 2015$ by the Government of the Socialist Republic of Vietnam on electronic Government (2015); Decree No $64 / 2007 /$ ND-CP promulgated on $10 / 04 / 2007$ by the Government of the Socialist Republic of Vietnam, on applying information and technology to the operation of State organizations (2007); Instruction No15/CT-TTg on 22/5/2012 by The Prime Minister of the Socialist Republic of Vietnam on boosting the use of electronic archival records in the State organizations' operation (2012), etc.; yet we lack legal documents regulating the electronic archival records processing in businesses, creating difficulties for non-state organizations in their operation in general and in their electronic archival records management in particular, which is always said to be unstable, unsystematic and inobjective.

Thirdly, laws and instruction documents are still general, being short of rules on the punishment to individuals, organizations and state units which do not use the electronic archival records exchange and management or limit its development. This shortcoming has been making it hard for the Government of Vietnam in their handling of the organizations and state units which do not commit to carrying out electronic trading and exchange.

Fourthly, the regulations on legal values of electronic data have been a big challenge in the industrialization of the Electronic Government; and at the very same time an encumbrance in the process of replacing paper materials with electronic or digital records. The current regulations on digital signatures have already been applied in electronic trading; however, there exist some risks which have not been yet mentioned in regulations so as to ensure the information safety of material sources in electronic environment such as the safety level of the digital signatures, digital signature being stolen, being illegally changed to other person, copyright problems, electronic archival records being changed without leaving a tracking and original versions, etc.

Fifthly, the system of legal documents of the Government of Vietnam lacks documents regulating and instructing professional skills and techniques in the electronic record processing such as filing electronic archival records, collecting and supplementing digital materials, appraising electronic materials and records; getting access, using and preserving electronic archival records in organizations and state units. Furthermore, Vietnam has not got strategic documents which would be able to guide individuals, organizations, state units who are interested in the management of electronic archival records and materials. 


\subsection{In terms of technological equipment supporting the electronic archival records treatment}

Technological equipment has played a crucial role in electronic archival records and material processing because all the documents and materials are issued, processed and recorded in the electronic environment. Humans cannot receive them directly without the supporting equipment or printed papers. Information in electronic archival records are formatted and filed in the physical information carriers (with high density in magnetic or optic equipment) to which humans cannot get direct access and is represented via symbols that need decoding.

However, the statistics on the application of technology in the electronic archival records treatment in State units has shown that:

- The rate of progress in the construction of national database is very slow. There have been so far two projects which have been completed their national database on administrative procedures on the internet and national database on commercial and industrial economy;

- While $88 \%$ of cadres, employees, state officials working in ministries and units belonging to the Government have applied information and technology in the electronic environment when they work with digital records; this figure does not apply to local level, and they mainly occur in the fields of customs, taxation, treasury and budget management;

- $86 \%$ of cadres, government officials at provincial and city levels are supplied with computers; at lower levels, the statistics is not that high.

- The percentages of electronic documents summited to the Government by ministries and units under the direction of Government and by cities and provinces under the jurisdiction of the central government are $97 \%$ and $75 \%$ respectively; Lower levels have not yet exploited or developed to the full the functions of the electronic correspondence system ${ }^{2}$.

\subsection{In terms of human resources performing the electronic archival records processing in organiza- tions and state organs}

There are many managing leaders and employees in organizations and state units in Vietnam who have not yet adapted themselves to the changes in documents and materials management and processing, from the traditional printed papers to electronic data. Hence, the management and processing of electronic archival records still have many limitations, which are said to be unsystematic and asynchronous.

On the other hand, their recognition of the risks and the confidentiality in the electronic archival records management are not high, creating some difficulties for the organizational operation. There have been electronic archival records where contents have been changed, digital documents have been used illegally, and database have been hacked, which worries electronic archival records users, causing doubt when getting access to or treating electronic archival records.

Besides, there still lacks the cooperation and co-ordination between archivists and cadres with knowledge and skills in information and technology; that is not to mention negative impacts on eye sight, nerves when people stay in long contact with computer monitors - the main equipment interfacing the electronic archival records management that the cadres working in the archival job have to face.

\section{Some solutions to the electronic archival records management in Vietnam nowadays}

Electronic archival records management work has a great influence on the activity of filing electronic archival records in particular and on the scientific unitization of electronic archival records in general in different organizations and state units. In the future, Vietnam and appropriate authorities and units need to produce systematic and synchronous measures in order to promote this essential operation.

\footnotetext{
2. According to Nguyen Hong Quan: the situation of applying information and technology and using electronic documents in the operation of the state units, in the summary record of the scientific workshop on filing electronic archival records in organizations and state units in Vietnam, State Records Management and Archives Department of Vietnam, 2016.
} 
4.1 Vietnam needs to issue implementation documents to boost and ensure the smooth operation of the electronic archival records system

The regulations should focus on such contents as:

- Enforcing the implementation of managing, unitizing and exchanging electronic archival records on the Internet according to the procedures appropriate to each organizations and units. Legal documents need to have detailed regulations on principles and process of electronic archival records exchange online; and have professional guidance on procedures and process in electronic materials management at different organizations and units.

- Instructing how to set up a project and carry out the management of electronic materials and documents. The digital records management project is a legal base, helping various organizations and state units implement the handling of scientifically electronic materials to a strict standard. Such projects should pay close attention to developing the electronic archival records management system, which includes technological equipment, management software. As for state units, they need unified electronic archival records management software which helps form the mega-data source for the nation.

- Making clear the standards system of the electronic archival records such as standards for mega-data, standards for formality, standards for formatting electronic archival records, standards for information contents, etc. which are all based on the results of the detailed research done by authorized organizations; encouraging organizations and state units to apply ISO 15489:2001 to their electronic archival records management ${ }^{3}$.

- Researching and focusing on regulations on electronic archival records management in system of businesses - a group that has been carrying out pretty well the management of digital records. The regulations for this group should be unified so that their operations in connection with electronic materials follow the same mode and method.

- Clarifying the regime of punishments against the violations in electronic archival records management; ensuring the legality of the electronic archival records; regulating the document exchange between organizations via formal exchange address set up by the unitization; and ensure that the information value and material security are much higher than if they are sent via email services such as Gmail, Yahoo or Hotmail.

4.2 Vietnam needs investment in material conditions, expenses and equipment serving the electronic archival records processing process

The State should provide moderate budget to organizations and state units to help them in their installation of computers, software, technology and internet connection used in the process of electronic archival records management and processing.

The State at the same time should supply organizations with a regulation that requires unified software construction in the digital records management among groups/systems of organizations in specific fields.

\subsection{Vietnam needs policies on capacity building on the field of electronic archival records processing at organizations and state units}

The legal documents should include the crucial roles of electronic materials and records, which should have some part in raising the awareness of managing leaders and employees on the importance of electronic archival records in solving work in an unitization.

In schools, the education programs for a major in archival management need to have the subjects or credits on information and technology. In organizations and companies, there should be training courses on information and technology, cyber security for personnel in order to keep to the minimum the possibility of electronic materials being changed, altered and violated or of databases being hacked, etc.

3. ISO 15489:2001 - "Information and materials" constructed basing on AS 4390 (Australian Standardization) on records management. ISO 15489 designed to meet the demand of archiving records and used by governmental and non-governmental organizations worldwide. 
In addition, it needs the coordination between archivists and cadres with knowledge and skills in technology. The personnel of archival work should be people educated in either the fields of archival studies and/or information - technology.

The State of Vietnam also needs to pay close attention to the physical and mental life of cadres and employees doing the archival work in general and employees doing electronic materials and records processing in particular in order to build up the love for their profession amongst themselves.

\section{Conclusion}

In conclusion, the electronic archival records management is significant in helping various organizations and state units control both materials (in terms of quantity and formality) and information contents in their database. Thus, to improve the capacity of ensuring the materials safety, ease of access to and effective use of electronic materials and records, the State of Vietnam needs to have positive measures in developing this operation. The basic solutions are: having detailed, sufficient and synchronous system of legal documents on electronic archival records processing; equipping organizations and offices with technological appliances serving the electrical records processing and management; and importantly enhancing the technological skills and knowledge of the cadres and employees working at archival organizations and offices from central to local levels. With all these solutions in reality, the management and processing of the electronic materials and records would be done efficiently, yielding fruitful productivity in the operation of each unitization and office.

\section{References}

1. Nguyễn Thị Chinh: Xây dựng các yêu cầu và giải pháp quản lý tài liệu điện tử - Đề tài cơ sở Cục Văn thư và Lưu trữ Nhà nước, Mã số 2009-98-02, HN, 2010.

2. Chính phủ: Nghị định số $01 / 2013 / \mathrm{NĐ-CP} \mathrm{ngày} \mathrm{03/1/2013} \mathrm{quy} \mathrm{định} \mathrm{chi} \mathrm{tiết} \mathrm{thi} \mathrm{hành} \mathrm{một} \mathrm{số} \mathrm{điều} \mathrm{của} \mathrm{Luật}$ Lưu trữ.

3. Chính phủ: Nghị định số 64/2007/NĐ-CP ngày 10/4/2007 về ứng dụng công nghệ thông tin trong hoạt động của các cơ quan nhà nước.

4. Chính phủ: Nghị định số 26/2007/NĐ-CP năm 2007 Quy định chi tiết thi hành Luật Giao dịch điện tử về chữ ký số và dịch vụ chửng thực chữ ký số.

5. Chính phủ: Nghị định 43 năm 2011 Quy định về việc cung cấp thông tin và dịch vụ công trực tuyến trên trang thông tin điện tử hoặc cổng thông tin điện tử của cơ quan nhà nước.

6. Chính phủ: Nghị quyết số 36a/2015/NQ-CP năm 2015 về Chính phủ điện tử.

7. Cục Văn thư và Lưu trữ Nhà nước: Hướng dẫn số 822/HD-VTLTNN ngày 26 tháng 8 năm 2015 về việc huiớng dân quản lý văn bản đi, văn bản đến và lạp hồ sơ trong môi triờng mang.

8. Cục Văn thư và Lưu trữ Nhà nước: Quyết định số 176/QĐ-VTLTNN ngày 21 tháng 10 năm 2011 của Cục Văn thư và Lưu trữ Nhà nước ban hành quy trinh vả huớng dẫn thực hiện quy trinh số hóa tài liệu lưu trữ dể lạp bản sao bảo biểm và bản sao sü dung.

9. Cục Văn thư và Lưu trữ Nhà nước: Quyết định số 310/QĐ-VTLTNN ngày 21 tháng 12 năm 2012 của Cục Văn thư và Lưu trữ Nhà nước ban hành quy trình tạo lập cơ sở dữ liệu tài liệu lưu trữ.

10. Cục Văn thư và Lưu trữ Nhà nước: Hướng dẫn số 169/HĐ-VTLTNN ngày 10 tháng 3 năm 2010 của Cục Văn thư và Lưu trữ Nhà nước về Xây dựng cơ sở dữ liệu lưu trữ.

11. Cục Văn thư và Lưu trữ Nhà nước: Kỷ yếu Hội thảo khoa học - Thực tiễn lập HS điện tử tại các cơ quan, tổ chức ở VN, Cục Văn thư và Lưu trữ Nhà nước, HN năm 2016.

12. Đỗ Thu Hiền: "Nhũng nghiên cứu về tài liệu diện tủ tại Việt Nam " - khóa luận tốt nghiệp năm 2011.

13. Lê Tuấn Hùng: "Quản lý tài liệu diên tủ hinh thành trong hoat dộng của các cơ quan - Thực trạng và giải pháp" đề tài NCKH cấp trường - ĐHKHXH và NV, mã CS.2015.07, HN năm 2016.

14. Nguyễn Thị Thùy Linh: Nghiên cứu áp dụng tiêu chuẩn ISO 15489 vào quản lý tài liệu lưu trữ điện tử tại các lưu trữ lịch sử hiện nay, Luận văn Thạc sĩ ngành Lưu trữ, Hà Nội năm 2011.

15. Lê Văn Năng: Trao đổi về khái niệm "Tài liệu điện tử" và "Tài liệu số" http://www.archives.gov.vn/Pages/ Tin\%20chi\%20ti\%E1\%BA\%BFt.aspx?itemid=70\&listId=64c127ef-bb13-4c45-820f-d765e28eb7cc\&ws=content. 
16. Nguyễn Lệ Nhung: Quan niệm vềchức năng luiu trü trong thời đại điện tủu.nguồn http://www.vanthuluutru.com, Hà Nội năm $201 \dot{5}$.

17. Quốc hội: Luật số 51/2005/QH11 ngày 29/11/2005 ban hành Luật giao dịch diện tủ.Hà Nội năm 2005.

18. Quốc hội: Luật số 67/2006/QH11 ngày 29/6/2006 ban hành Luật công nghệ thông tin, Hà Nội năm 2006.

19. Quốc hội: Luật số 01/2011/QH13 ngày 11/11/2011 ban hành Luạt luiu trü, Hà Nội năm 2011.

20. Trường Đại học Nội vụ Hà Nội: Kỷ yếu Hội thảo khoa học "Quản lý tài liệu diện tủ và luiu trũ diện tử - Thực tiễn Việt Nam vả kinh nghiệm quốc tê", NXB Lao động, 2013.

21. Trường Đại học Nội vụ Hà Nội: Kỷ yếu Hội thảo khoa học "Lập hố sơ diện tử vả lưu trữ tài liệu diện tử, NXB Lao động, 2015.

\section{SUMMARY}

Archival records in the digital format (also called electronic archival records) are formed on the basis of data messages or documents digitized in information carriers during the operation of individuals, organizations and state offices. The Socialist Republic of Vietnam has issued some documents which act as legal base for the management of digital archival records, such as Electronic Exchange Law (2005), Information and Technology Law (2006), Archival Law (2011), Online Information Safety Law (2015) and other decrees and instructions circulars. However, the legal documents on regulations of the management of electronic archival records in general and the processing of electronic archival records in particular have been insufficient and unsystematic, posing difficulties to organizations and state offices when applying them into practice. In terms of the system of documents regulating and instructing the process of electronic archival records processing, Vietnam has not yet systemically promulgated regulation documents which would detail the online exchange process of electronic archival records, instructions related to material management and processing, technical requirements on material formatting, electronic mega data, and common software used in the archival operation of different organizations and state units. Besides, relevant laws and instructions are still general, being short of rules on the punishment to individuals, organizations and state units which do not join in the using of the electronic archival records exchange and management. In terms of technological equipment supporting the electronic archival records treatment, the construction of national database is happening slowly. In terms of human resources performing the electronic archival records treatment in organizations and state organs, many managing leaders and employees in organizations and state units in Vietnam have not yet adapted themselves to the changes in documents and materials management and processing, from the traditional printed papers to electronic data. Also, their awareness of the risks and the confidentiality in the electronic archival records management is not high. In the upcoming time, appropriate authorities and State organs need to produce systematic and synchronous measures in order to promote and better the handling of archival records in digital format. First, Vietnam needs to issue implementation documents to boost and ensure the smooth operation of the electronic records system. Second, it needs investment into material conditions, expenses and equipment serving the electronic records treatment process. Third, Vietnam needs policies on improving personnel capacity working in the field of electronic records treatment at organizations and state organs. With all the workable and possible solutions put in practice, the management and treatment of the electronic materials and records in Vietnam would be done efficiently, promisingly yielding fruitful productivity in the operation of each organization and office.

Typology: 1.04 Professional Article

Submitting date: 06.04.2017

Acceptance date: 05.05.2017 